\title{
INFLUENCE OF FACTORS PROMOTING FINANCIAL LITERACY ON THE ACHIEVEMENTS OF FINANCIAL LITERACY OF STUDENTS IN LATVIA
}

\author{
Linda Mihno \\ University of Latvia, Latvia
}

\begin{abstract}
The literature suggests that financial literacy depends on factors such as socioeconomic status/sociodemographic status, psychosocial and psychological factors, experience, and access to financial education, language skills, mathematical literacy and other factors. The aim of this study was to identify the factors that influence the financial literacy achievements of students from Latvia, focusing on the possibility to improve these achievements.

The data analysis was performed with PISA 2018 Latvian data, which there were selected 25\% of the participating students whose financial literacy performance was lower than the mean performance in mathematical and reading literacy and $25 \%$ of students whose financial literacy performance was considerably higher than the mean performance in mathematical literacy and reading literacy. Differences between these two groups showed factors that impact financial literacy achievements, excluding the possibility that the financial literacy performance of these students was high due to the mathematical and reading literacy.

It was concluded that the financial achievements of students in Latvia are positively influenced by such factors as the socioeconomic status/sociodemographic status, psychosocial factors, and psychological factors (students with higher financial literacy achievements have a more negative attitude towards school but a more positive attitude towards life, less fear of failure and more a positive attitude towards competition, and clear plans for the future), accessibility of the financial education, time devoted to financial education, an accessible wide range of financial topics in education, experience in the financial environment, parents' involvement, feedback from teachers in reading lessons.
\end{abstract}

Keywords: Achievements of financial literacy, Financial Literacy, Mathematic literacy, OECD PISA 2018, Reading literacy.

\section{Introduction}

Financial literacy is important for promoting well-being for whole society and for each individual. Actuality of development of financial literacy 
is undeniable considering previous financial crises in all over the world and Latvia too. Also the current epidemiological crisis clearly noted, how important is financial literacy. Each of us should know how to accumulate wealth and take care of well-being in order to be safe in unpredictable situations. Financial management should be learned in school, just as students learn other skills needed in adult life. Youngsters should understand the financial environment before they start to work and live on their own, in order to understand the need for taxes, accumulate wealth, and analyze financial choices to find those most suitable.

Policy-makers should to know what factors influence the development of financial literacy. It could help them to better understand how to decrease and increase the influence of factors, in order to arrange the education processes.

The definition of financial literacy underlines that financial literacy is formed by knowledge, skills, and the motivation to apply this knowledge. After analyzing the literature, it was found that the following factors influence the development of financial literacy:

- Socioeconomic status/sociodemographic status (Shults, 2012; Kaiser and Menkhoff, 2017; Põder et al., 2020; Firli, 2017; Vijay and Nardeep, 2018; Bashir et al., 2013; Atkinson and Messy, 2012; Jeyaram and Mustapha, 2015; Gangwar and Singh, 2018; Vig, 2017; Vyvyan et al., 2014).

- Psycho-social factors and psychological factors (Murphy, 2013; Vijay and Nardeep, 2018; Bashir et al., 2013; Bhargav and Mittal, 2017; Vyvyan et al., 2014; Venkataraman and Venkatesan, 2018).

- Accessibility of financial education (Venkataraman and Venkatesan, 2018; Firli, 2017; Bhargav and Mittal, 2017; Bruhn et al., 2016; Kaiser and Menkhoff, 2017; Tang and Peter, 2015; Moreno-Herrero et al., 2018).

- The time devoted to financial education (Kaiser and Menkhoff, 2017).

- Accessibility of wide range of financial topics in education (O'Neill et al., 2010).

- Teachers' knowledge (Põder et al., 2020).

- Mathematical literacy (Willis, 2008; Bhargav and Mittal, 2017; Jappelli and Padula, 2013; Barua et al., 2012).

- Language skills (Põder et al., 2020; Riitsalu and Põder, 2016).

- Analytical skills (Bhargav and Mittal, 2017).

- Experience in the financial environment (Hilgert et al., 2003; Lyons et al., 2006b; Kindle, 2013; Tang and Peter, 2015; Moreno-Herrero et al., 2018; Shults, 2012; Bhargav and Mittal, 2017).

- Parents' involvement (Hilgert et al., 2003; Lyons et al., 2006a; Cole et al., 2016; Moreno-Herrero et al., 2018; Tang and Peter, 2015; Sabri et al., 2010; Venkataraman and Venkatesan, 2018).

- Liquidity (Bhargav and Mittal, 2017). 
Various factors affected financial literacy, it is important to understand the impact of these factors on students' financial achievements. To understand the extent to which these factors affect the financial literacy achievement of students from Latvia, it is important to discover which opportunities promote the development of financial literacy. The aim of this study was to identify the factors that influence the financial literacy achievements of students from Latvia, focusing on the possibility to improve these achievements.

\section{Method}

The data analysis was performed with PISA 2018 Latvian data of which there were selected $25 \%$ of the participating students whose financial literacy performance was lower than the mean performance in mathematical and reading literacy (Group 1 ) and $25 \%$ of students whose financial literacy performance was considerably higher than the mean performance in mathematical literacy and reading literacy (Group 2). The Target Population for PISA are students between 15 years and 3 (completed) months and 16 years and 2 (completed) months at the beginning of the testing period, attending educational institutions located within the country, and in grade 7 or higher. Differences in various indices were sought between these groups in order to find out which factors could influence students' financial literacy performance, excluding the possibility that the financial literacy performance of these students was high due to mathematical and reading literacy. Hereafter, only those indices are discussed where the difference between these two groups is statistically significant with $95 \%$ reliability.

Table 1. Comparison of indices between students whose financial literacy performance was lower than the mean performance in mathematical and reading literacy and students whose financial literacy performance was considerably higher than the mean performance in mathematical literacy and reading literacy.

\begin{tabular}{|c|c|c|c|c|c|}
\hline Index & & 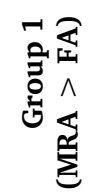 & 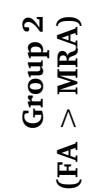 & 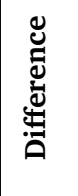 & Questions \\
\hline \multirow{3}{*}{$\begin{array}{l}\text { Economic, } \\
\text { social, and } \\
\text { cultural } \\
\text { status } \\
\text { (ESCS) }\end{array}$} & Mean & 0.11 & -0.14 & 0.24 & \multirow{3}{*}{$\begin{array}{l}\text { Parents' highest level of } \\
\text { education. } \\
\text { Parents' highest occupational } \\
\text { status. } \\
\text { Home possessions (a proxy } \\
\text { measure for family wealth) }\end{array}$} \\
\hline & SE & 0.05 & 0.05 & & \\
\hline & mnxdiff_t & \multicolumn{2}{|l|}{4.61} & & \\
\hline
\end{tabular}




\begin{tabular}{|c|c|c|c|c|c|}
\hline Index & & 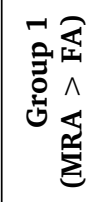 & 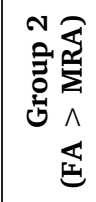 & 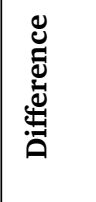 & Questions \\
\hline \multirow{3}{*}{$\begin{array}{l}\text { Value of } \\
\text { school }\end{array}$} & Mean & -0.22 & -0.48 & 0.26 & \multirow{3}{*}{$\begin{array}{l}\text { Trying hard at school will help me } \\
\text { get a good job. } \\
\text { Trying hard at school will help me } \\
\text { get into a good university. } \\
\text { Trying hard at school is } \\
\text { important. }\end{array}$} \\
\hline & SE & 0.05 & 0.05 & & \\
\hline & mnxdiff_t & \multicolumn{2}{|l|}{5.02} & & \\
\hline \multirow{3}{*}{$\begin{array}{l}\text { Positive } \\
\text { feelings }\end{array}$} & Mean & -0.10 & 0.12 & -0.22 & \multirow{3}{*}{$\begin{array}{l}\text { Happy } \\
\text { Joyful } \\
\text { Cheerful }\end{array}$} \\
\hline & SE & 0.06 & 0.06 & & \\
\hline & mnxdiff_t & \multicolumn{2}{|l|}{3.85} & & \\
\hline \multirow{3}{*}{$\begin{array}{l}\text { Meaning in } \\
\text { life }\end{array}$} & Mean & -0.17 & -0.03 & -0.14 & \multirow{3}{*}{$\begin{array}{l}\text { My life has clear meaning or } \\
\text { purpose. } \\
\text { I have discovered a satisfactory } \\
\text { meaning in life. } \\
\text { I have a clear sense of what gives } \\
\text { meaning to my life. }\end{array}$} \\
\hline & SE & 0.05 & 0.05 & & \\
\hline & mnxdiff_t & 2.99 & & & \\
\hline \multirow{3}{*}{$\begin{array}{l}\text { Fear of } \\
\text { failure }\end{array}$} & Mean & 0.04 & -0.19 & 0.23 & \multirow{3}{*}{$\begin{array}{l}\text { When I am failing, I worry about } \\
\text { what others think of me. } \\
\text { When I am failing, I am afraid } \\
\text { that I might not have enough } \\
\text { talent. } \\
\text { When I am failing, this makes me } \\
\text { doubt my plans for the future. }\end{array}$} \\
\hline & $\mathrm{SE}$ & 0.05 & 0.05 & & \\
\hline & mnxdiff_t & 4.47 & & & \\
\hline \multirow{3}{*}{$\begin{array}{l}\text { Student } \\
\text { competition }\end{array}$} & Mean & -0.09 & 0.03 & -0.13 & \multirow{3}{*}{$\begin{array}{l}\text { Students seem to value } \\
\text { competition. } \\
\text { It seems that students are } \\
\text { competing with each other. } \\
\text { Students seem to share the feeling } \\
\text { that competing with each other is } \\
\text { important. }\end{array}$} \\
\hline & SE & 0.06 & 0.06 & & \\
\hline & mnxdiff_t & 2.18 & & & \\
\hline \multirow{3}{*}{$\begin{array}{l}\text { Attitudes } \\
\text { towards } \\
\text { competition }\end{array}$} & Mean & -0.09 & 0.06 & -0.15 & \multirow{3}{*}{$\begin{array}{l}\text { I enjoy working in situations } \\
\text { involving competition with } \\
\text { others. } \\
\text { It is important for me to perform } \\
\text { better than other people on a task. } \\
\text { I try harder when I'm in } \\
\text { competition with other people. }\end{array}$} \\
\hline & SE & 0.05 & 0.05 & & \\
\hline & mnxdiff_t & 2.74 & & & \\
\hline \multirow{3}{*}{$\begin{array}{l}\text { Teacher } \\
\text { support }\end{array}$} & Mean & 0.08 & -0.04 & 0.12 & \multirow{3}{*}{$\begin{array}{l}\text { The teacher shows an interest in } \\
\text { every student's learning. } \\
\text { The teacher gives extra help when } \\
\text { students need it. } \\
\text { The teacher helps students with } \\
\text { their learning. } \\
\text { The teacher continues teaching } \\
\text { until the students understand. }\end{array}$} \\
\hline & SE & 0.04 & 0.04 & & \\
\hline & mnxdiff_t & 2.70 & & & \\
\hline
\end{tabular}




\begin{tabular}{|c|c|c|c|c|c|}
\hline Index & & 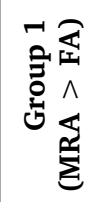 & 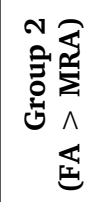 & 遌 & Questions \\
\hline \multirow{3}{*}{$\begin{array}{l}\text { Teacher } \\
\text { feedback }\end{array}$} & Mean & 0.07 & 0.22 & -0.15 & \multirow{3}{*}{$\begin{array}{l}\text { The teacher gives me feedback on } \\
\text { my strengths in this subject. } \\
\text { The teacher tells me in which } \\
\text { areas I can still improve. } \\
\text { The teacher tells me how I can } \\
\text { improve my performance. }\end{array}$} \\
\hline & SE & 0.05 & 0.05 & & \\
\hline & mnxdiff_t & \multicolumn{2}{|l|}{2.84} & & \\
\hline \multirow{3}{*}{$\begin{array}{l}\text { Index of } \\
\text { confidence } \\
\text { in dealing } \\
\text { with money } \\
\text { matters. }\end{array}$} & Mean & -0.10 & 0.23 & -0.34 & \multirow{3}{*}{$\begin{array}{l}\text { How confident you feel } \\
\text { performing the following tasks } \\
\text { when using digital or electronic } \\
\text { devices outside of a bank: } \\
\text { - making a money transfer (e. g. } \\
\text { paying a bill) } \\
\text { - filling in forms at the bank } \\
\text { - understanding bank statements } \\
\text { - understanding a sales contract } \\
\text { - keeping track of [their] account } \\
\text { balance } \\
\text { - planning [their] spending in } \\
\text { consideration of [their] current } \\
\text { financial situation. }\end{array}$} \\
\hline & SE & 0.06 & 0.06 & & \\
\hline & mnxdiff_t & \multicolumn{2}{|l|}{5.35} & & \\
\hline \multirow{3}{*}{$\begin{array}{l}\text { Index of } \\
\text { confidence } \\
\text { in using } \\
\text { digital } \\
\text { financial } \\
\text { services }\end{array}$} & Mean & -0.18 & 0.12 & -0.30 & \multirow[b]{3}{*}{$\begin{array}{l}\text { How confident you feel } \\
\text { performing the following tasks } \\
\text { when using digital or electronic } \\
\text { devices outside of a bank: } \\
\text { - transferring money } \\
\text { - keeping track of their balance } \\
\text { - paying with a debit card instead } \\
\text { of using cash } \\
\text { - paying with a mobile device } \\
\text { (e. g. mobile phone or tablet) } \\
\text { instead of using cash } \\
\text { - ensuring the safety of sensitive } \\
\text { information when making an } \\
\text { electronic payment or using } \\
\text { online banking. }\end{array}$} \\
\hline & SE & 0.05 & 0.05 & & \\
\hline & mnxdiff_t & \multicolumn{2}{|l|}{5.73} & & \\
\hline \multirow{3}{*}{$\begin{array}{l}\text { Index of } \\
\text { financial } \\
\text { education } \\
\text { in school } \\
\text { lessons }\end{array}$} & Mean & -0.09 & 0.12 & -0.21 & \multirow{3}{*}{$\begin{array}{l}\text { Students were asked about the } \\
\text { frequency (never, sometimes } \\
\text { or often) with which they had } \\
\text { encountered six personal } \\
\text { finance-related tasks in school } \\
\text { lessons over the previous } 12 \\
\text { months: } \\
\text { - describing the purpose and uses } \\
\text { of money } \\
\text { - exploring the difference between } \\
\text { spending money on needs and } \\
\text { wants }\end{array}$} \\
\hline & SE & 0.05 & 0.05 & & \\
\hline & mnxdiff_t & 3.99 & & & \\
\hline
\end{tabular}




\begin{tabular}{|l|l|l|l|l|}
\hline Index & & & & $\begin{array}{l}\text { Questions } \\
\text { - exploring ways of planning to } \\
\text { pay an expense } \\
\text { discussing the rights of } \\
\text { consumers when dealing with } \\
\text { financial institutions } \\
\text { discussing the ways in which } \\
\text { money invested in the stock } \\
\text { market changes value over time } \\
\text { analysing advertisements to } \\
\text { understand how they encourage } \\
\text { people to buy things. }\end{array}$ \\
\hline
\end{tabular}

MRA - mathematics literacy and reading literacy achievement

FA - finance literacy achievements

SE - standard erro

\section{Results}

Table 1 summarizes only those indices where the difference between these two groups is statistically significant with $95 \%$ reliability. Indices are formed by using student answers to specific questions. A positive value of the index means that a particular country has a more positive attitude towards a particular issue than the OECD average. The individual is given the opportunity to examine some of the factors influencing financial literacy.

\section{Discussion}

Families who are better off financially are expected to be able to manage their finances better and children are also better educated in finance and have a better understanding of cash flow. However, the data show that ESCS has a greater impact on students' achievement in mathematics literacy and reading literacy than on financial literacy achievement. The difference in the ESCS index is 0.24. Although, an increase in ESCS could also lead to higher financial literacy achievements, but the impact will not be so great. ESCS is one of the most mentioned factors that has influenced financial literacy (Shults, 2012; Kaiser and Menkhoff, 2017; Põder et al., 2020; Firli, 2017; Luksander et al., 2014).

Among the analyzed groups, students with higher financial literacy are much more positive compared to the OECD average, and these students have 
a much better understanding of the meaning and significance of life and have already found their purpose in life. Probably that is the reason why these students have a more positive attitude towards life and everything that is going on around it. Bhargav and Mittal (2017) claim something similar, if a student knows what he wants to do in the future, then it influences financial literacy level.

It is also not surprising that these students are less afraid of failure, they are not afraid of making mistakes, which is essential for promoting financial literacy when thinking about risks and future plans. These students feel competition much more and they claim that the competition has a positive effect on them. They like to compete with others, which is the driving force of the financial world to achieve higher results.

Students with higher levels of financial literacy were more confident with their money management skills, such as making payments, filling out bank forms, reading bank statements, reading purchase agreements, keeping track of their account balance, and planning their expenses according to their current situation. Vyvyan et al. (2014) and Venkataraman and Venkatesan (2018) found that confidence in self-financial skills largely determines financial literacy. Also these students feel more confident with using the services of digital financial instruments such as money transfers, checking account balances, using a payment card, using a digital device to make payments, and taking care of their safety when using these devices. Probably it is because students use these tools more on a daily basis and have access to them. A bank account, a payment card/debit card and a mobile application are used more by students with higher levels of financial literacy than in mathematics and reading. This proves that the use of financial tools improves students financial literacy, and increases understanding of the financial environment.

Students with higher levels of financial literacy do not have such a positive attitude towards school. Students from Latvia believe that a school plays an important role in getting a better-paid job or entering a university and it is less than the OECD average. Overall, this index is negative for both groups. In contrast, this is the case in Estonia and Finland, where attitudes towards school are more positive than the OECD average (OECD, 2019a). This negative index demonstrates the prevailing views in Latvian society. Riga Distance Learning Secondary School in cooperation with the Market and Public Opinion Research Center SKDS implemented a study. In this study was found that almost half of the Latvian population expressed the opinion that education in Latvia is at a medium level and $21 \%$ thought that the quality of education is currently low in Latvia. Those who have children assessed the quality of education as the lowest (Leta, 2019). Therefore, it is not surprising that students think that school is not important for their 
future. Students' attitudes towards school have more impact on their mathematics and reading literacy achievements than financial literacy achievements. Countries with higher achievement showed a more positive attitude towards school than the OECD average in every study field. There could be more than one reason why students' attitude towards school has less impact on the students' financial literacy achievement:

- Most of the students with high financial literacy achievements claimed that they have not studied finance at school.

- They learned about finance in extracurricular activities and looked for information themselves.

- Currently the financial topic is compulsory only in the social science subject.

However, those students who learned about finance at school have higher financial literacy achievements than mathematics and reading literacy achievements. The difference in the index of financial education in school lessons is 0.21 points. This means that these students more often have encountered the following types of tasks or activities in school lessons like describing the purpose and uses of money, exploring the difference between spending money on needs and wants, exploring ways of planning to pay an expense, discussing the rights of consumers when dealing with financial institutions, discussing the ways in which money invested in the stock market changes value over time, and analyzing advertisements to understand how they encourage people to buy things. Obviously, this positively affected their financial literacy and let them achieve higher scores in the assessment of financial literacy.

The Hungarian National Audience Office has also found that students who have attended fewer lectures show higher levels of financial literacy, although those who have attended specialized courses related to economics have still higher levels of financial literacy (Luksander et al., 2014). Therefore, it is important that students talk about finance at school in order to improve the financial literacy achievements.

The teacher is important to develop financial literacy. Teachers who teach students about finance must be appropriately educated. However, not only these teachers but also other teachers influence the students' financial literacy achievements. For example, in PISA 2018 the main area was reading, so students were asked questions about reading lessons and teachers' activities in them. If we look at the index "Teacher Support" which consisted of questions that show how much the teacher is involved and interested in the student's ability to understand what is being taught and to identify and eliminate problems, teacher's support in reading lessons has a much greater impact on mathematics literacy and reading literacy achievements. For students with higher financial literacy achievements, this 
index is negative. These students are more independent and they feel that they can do much more by themselves, and such large teachers' involvement is not necessary.

In contrast, the index "Teacher Feedback" is higher for students with higher financial literacy achievements. This means that these students more often receive feedback from teachers about their work. The teachers point out areas which students should work on, so that students have a better understanding of how to improve their work. Financial literacy achievements are largely determined by the ability to express an opinion. Data showed that students reach higher achievements when teachers more often express an opinion, offer criticism, and teach that mistakes mean learning. Feedback from teachers is necessary although it is a test language lesson. During these lessons, students read, express their opinion about what they have read, write various augmented essays and similar things, which are also necessary for financial literacy.

The frequency with which parents talk about finance with their children, such as children's spending, savings, including a family budget, expenses, and news related to economics or finance also have an impact on financial literacy achievements. However, this difference between the two groups is not statistically significant. Parental involvement is important in fostering children's financial literacy. Especially, if the school does not have a fullfledged subject, where students learn about finance that is important for their daily lives to promote an understanding of the financial world and the ability to succeed in the future. This all works only if the parents themselves are sufficiently competent in finance.

In the literature, experience in the financial environment is mentioned as an important factor in promoting financial literacy. When students manage their own money (pocket money, donated or self-earned) it forms students' experience in the financial environment (Shults, 2012; Bhargav un Mittal, 2017; Moreno-Herrero et al., 2018).

Students who have a payment card, account, or mobile application have higher levels of financial literacy. They have experience and knowledge of how these tools work. They are also able to apply their knowledge in order to solve various tasks related to finance.

The OECD also points out that digital financial services are becoming increasingly popular and play an important role in everyday life. Young people can be supported through the formal school curriculum: wherever this includes financial education, its content should be enhanced with financial education for DFS (Digital Financial Services), even more so in the light of the use of digital tools and the preference for digital experiences of the younger generations, which may outweigh those of their parents (OECD, 2018). 
In order to find factors the researcher used PISA student questionnaire; there was not an opinion to get extra information that could be useful. The second limitation of the research is that PISA in Latvia did not use questionnaires for teachers, so it was not possible to find out there opinions about the learning process. PISA did not find out teachers' knowledge in financial literacy, so the researcher was not able to find out how teachers' knowledge could have influenced student financial literacy.

\section{Conclusions}

Financial literacy achievements for students from Latvia are related to factors like:

- The socioeconomic/sociodemographic status, which affect students' literacy in mathematics, reading and also in finance, however, the impact on financial literacy is not so great;

- Psychosocial factors and psychological factors, students with higher financial literacy achievements have a more negative attitude towards school but a more positive attitude towards life, less fear of failure and more positive attitude towards competition, and clear plans for the future.

- Accessibility of financial education, time deveroted to financial education, a wide range of financial topics accessible in education;

- Experience in the financial environment. Those students who use financial instruments, such as a bank account, payment card and mobile applications, are not only convinced of their financial instrument management skills, but they also show the highest level of financial achievements.

- Parents' involvement: Parental involvement is important in fostering children's financial literacy. That works if the parents themselves are sufficiently competent in finance.

- Feedback from teachers. Students with higher financial literacy achievements feel less support from teachers in reading lessons. It does not affect their financial literacy achievements. The feedback provided by teachers is very important for these students, which is also an important cornerstone of the new educational standards.

\section{References}

Atkinson, A., Messy, F. (2012). Measuring Financial Literacy: Results of the OECD/ International Network on Financial Education(INFE) Pilot Study. OECD Working Papers on Finance, Insurance and Private Pensions, No. 15, OECD Publishing.

Barua, M., Bhagwat S. A., \& Jadhav S. (2013). The hidden dimensions of human-wildlife conflict: Health impacts, opportunity and transaction costs. Biol. Conserv., 157, 309-316. 
Bashir, T., Arshad, A., Nazir, A. \& Afzal, N. (2013). Financial literacy and influence of psychosocial factors. European Scientific Journal, 9(28), 384-404.

Bhargav, N. R., Mittal, S. (2017). A Study of Determinants Influencing Financial Literacy of Individual Investor in India. International Journal of Research and Innovation in Social Science (IJRISS)1(3), 22-27.

Bruhn, M., de Souza Leao, L., Legovini, A., Marchetti, R., \& Zia, B. (2016). The Impact of High School Financial Education: Evidence from a Large-Scale Evaluation in Brazil. American Economic Journal: Applied Economics 8 (4), 256-295.

Cole, S., Paulson, A., \& Shastry, G. K. (2016). High school curriculum and financial outcomes: The impact of mandated personal finance and mathematics courses. Journal of Human Resources, 51(3), 656-698.

Firli, A. (2017). Factors that Influence Financial Literacy: A Conceptual Framework. IOP Conf. Series: Materials Science and Engineering, 180. https://doi.org/10.1088/1757-899X/ $180 / 1 / 012254$

Gangwar, R., Singh, R. (2018). Analyzing Factors Affecting Financial Literacy and its Impact on Investment Behavior among Adults in India. MPRA Paper No. 89452, 1-24.

Hilgert, M. A., Hogarth, J. M., Beverly, S. G. (2003). Household financial management: the connection between knowledge and behaviour. Federal Reserve Bulletin, 89, 309-322.

Jappelli, T., Padula, M. (2013). Investment in Financial Literacy and Saving Decisions. Journal of Banking and Finance, 37(8), 2779-2792.

Jeyaram, S., Mustapha, M. (2015). Financial literacy and demographic factors. Journal of Technology Management and Business, 2(1), 1-8.

Kaiser, T., Menkhoff, L. (2017). Does Financial Education Impact Financial Literacy and Financial Behavior, and If So, When? The World Bank Economic Review, 31(3), 611-630.

Kindle, P. A. (2013). The Financial Literacy of Social Work Students. Council on Social Work Education. Journal of Social Work Education, 49, 391-401. https://doi.org/10.108 0/10437797.2013.796853

Leta (2019). Pētijums: teju 50\% iedzivotāju izglitīibas kvalitāti Latvijā vērtē kā viduvēju. (Research: almost $50 \%$ of the population in Latvia evaluate the quality of education as mediocre.) Dzirkstele.lv. Retrieved from: https://www.dzirkstele.lv/latvijas-zinas/petijums-teju50-proc-iedzivotaju-izglitibas-kvalitati-latvija-verte-ka-viduveju-171348

Luksander, A., Béres, D., Huzdik, K., \& Németh, E. (2014). Analysis of the Factors that Influence the Financial Literacy of Young People Studying in Higher Education. Public Finance Quarterly, State Audit Office of Hungary, 59(2), 220-241.

Lyons, A., Chang, Y., Scherpf, E. (2006a). Translating financial education into behavior change for low-income populations. Journal of Financial Counseling and Planning, 17(2), 27-45.

Lyons, A. C., Palmer, L., Jayaratne, K. S. U., \& Scherpf, E. (2006b). Are We Making the Grade? A National Overview of Financial Education and Program Evaluation. The Journal of Consumer Affairs, 40(2), 208-235.

Moreno-Herrero, D., Salas-Velasco, M., \& Sánchez-Campillo, J. (2018). Factors that influence the level of financial literacy among young people: The role of parental engagement and students' experiences with money matters. Children and Youth Services Review 95, 334-351.

Murphy, J. L. (2013). Psychosocial Factors and Financial Literacy. Social Security Bulletin, 73(1), 73-81. 
O’Neill, B., Porter, N. M., Pankow, D., Schuchardt, J., \& Johnson, J. (2010). Online Investment Education: Listening to Learners to Develop an Effective Financial Literacy Program for Farm Households. Journal of Financial Counseling and Planning. 21(1), 25-42.

OECD (2018). G20/OECD INFE Policy Guidance on Digitalisation and Financial Literacy.

OECD (2019a). PISA 2018 Results (Volume III): What School Life Means for Students' Lives. PISA, OECD Publishing, Paris. https://doi.org/10.1787/acd78851-en.

Põder, K., Riitsalu, L., \& Kroos, K. (2020). Financial education in Estonia. Financial education: Current practices and future challenges. Waxmann Verlag, 87-109.

Riitsalu, L., Põder, K. (2016). A glimpse of the complexity of factors that influence financial literacy. International Journal of Consumer Studies 40(6), 722-731. https://doi. org/10.1111/ijcs.12291

Sabri, M. F., Macdonald, M., Hira, T., \& Masud, J. (2010). Childhood Consumer Experience and the Financial Literacy of College Students in Malaysia. Family and Consumer Sciences Research Journal. 3, 455-467. https://doi.org/10.1111/j.1552-3934.2010.00038.x.

Shults, S. D. (2012). Financial Literacy of High School Seniors. A Dissertation Submitted to the Graduate Faculty of The University of Georgia. Athens, Georgia.

Tang, N., Peter, P. C. (2015). Financial knowledge acquisition among the young: The role of financial education, financial experience, and parents' financial experience. Financial Services Review, 24(2), 119-137.

Venkataraman, R., Venkatesan, T. (2018). Analysis of Factors Determining Financial Literacy using Structural Equation Modelling. SDMIMD Journal of Management, 9(1), 19-29.

Vig, S. (2017). Assessment of Factors Affecting Financial Levels of Indian Investors. Journal of Advanced Computing and Communication Technologies, 5(3), 93-97.

Vijay, L., Nardeep, K.M. (2018). Identification of Factors Influencing Financial Literacy: A Theoretical Review. International Journal of Research in Management, Economics and Commerce, 8(1), 89-94.

Vyvyan, V., Blue, L. \& Brimble, M. (2014) Factors that Influence Financial Capability and Effectiveness: Exploring Financial Counsellors' Perspectives. Australasian Accounting, Business and Finance Journal, 8(4), 3-22. Retrieved from: http://ro.uow.edu.au/aabfj/ vol8/iss $4 / 2$

Willis, L. E. (2008). Against financial literacy education. Iowa Law Review 94, 8-10. 